\title{
Portable Circulating Adsorption Column Design for Seawater Purification
}

\section{Desain Kolom Adsorpsi Portabel Bersirkulasi untuk Pemurnian Air Laut}

\author{
Mohammad Prasanto Bimantio ${ }^{1}$, Amallia Ferhat ${ }^{2}$ \\ ${ }^{1}$ Teknologi Hasil Pertanian, Institut Pertanian STIPER Yogyakarta \\ Jl. Nangka II, Maguwoharjo, Depok, Sleman \\ ${ }^{2}$ Ekonomi Pertanian, Institut Pertanian STIPER Yogyakarta \\ Jl. Nangka II, Maguwoharjo, Depok, Sleman \\ email : bimantiomp@instiperjogja.ac.id \\ doi: https://doi.org/10.31315/opsi.v14i2.5127
}

Received: 12 ${ }^{\text {nd }}$ July 2021; Revised: 20 th August 2021; Accepted: $26^{\text {th }}$ August 2021;

Available online: $21^{\text {st }}$ December 2021; Published regularly: December 2021

\begin{abstract}
Seawater is one of the largest natural resources and abundant in Indonesia, which contains salt, metals and mycobacteria. Even though the amount is abundant, its utilization is still not widespread, such as to be used as clean water or drinking water. The use of adsorbents aims to adsorb impurities in the fluid. The adsorption column that is widely used is in the form of a fixed-bed column with messy stacked filling. This makes it difficult to clean and fill the adsorbent, besides the irregular pile of adsorbents will hinder the flow process of the purified fluid. The research product is a circulating portable adsorption column design consisting of 3 parts, namely: top distributor, packing bed, and bottom collector. The principle of the three parts is like a puzzle where the number of packing beds can be adjusted according to the purification needs. The three parts are connected with threads so that they can be disassembled as desired. It is hoped that this product can meet the needs of adsorption-based purification that is easy, inexpensive, and can be customized according to various types of adsorbents. The design of this product can be duplicated for other adsorption purification processes, such as purification of bioethanol, wastewater, and biodiesel.
\end{abstract}

Keywords: adsorption, seawater, column, purification

\begin{abstract}
ABSTRAK
Air laut merupakan salah satu sumber daya alam terbesar di Indonesia, yang mengandung garam, logam dan mikobakteri. Meskipun sumber dayanya melimpah, pemanfaatannya masih belum meluas, seperti digunakan sebagai air bersih atau air minum. Penggunaan adsorben dimaksudkan untuk mengadsorbsi pengotor dalam fluida. Kolom adsorpsi yang banyak digunakan dalam bentuk kolom unggun tetap, dan kemasan yang dikemas tidak teratur. Ini membuat adsorben sulit dibersihkan dan diisi, dan akumulasi adsorben yang tidak teratur dapat menghambat aliran cairan. Produk penelitian adalah desain menara adsorpsi portabel yang bersirkulasi, terdiri dari tiga bagian, yaitu: distributor atas, packing bed, dan kolektor bawah. Prinsip tiga bagian seperti sistem bongkar pasang, jumlah media yang dipasang dapat disesuaikan dengan kebutuhan pemurnian. Tiga bagian dihubungkan oleh ulir dan dapat dibongkar pasang sesuai kebutuhan. Alat ini harapannya dapat memenuhi kebutuhan pemurnian berbasis adsorpsi yang mudah, murah, dan dapat dikustomisasi sesuai dengan berbagai jenis adsorben. Desain alat ini dapat diduplikasi untuk proses pemurnian adsorpsi lainnya, seperti pemurnian bioethanol, air limbah, dan biodiesel.
\end{abstract}

Kata Kunci: adsorpsi, air laut, kolom, pemurnian 


\section{PENDAHULUAN}

Adanya sumber air bersih yang terbatas membuat masyarakat sering menghadapi masalah yang sulit, di sisi lain kebutuhan juga semakin meningkat seiring dengan pertumbuhan penduduk. Situasi ini tidak hanya terjadi di perkotaan dan pedesaan, tetapi juga di wilayah pesisir dan pulau-pulau di tengah laut lepas. Daerah pesisir dan pulau-pulau yang jauh dari kota merupakan daerah dengan sumber air bersih yang sangat minim. Sumber air di daerah ini biasanya kualitas airnya buruk, seperti air tanah asin.

Air laut merupakan salah satu sumber daya alam terbesar di Indonesia, yang mengandung garam, partikel logam dan mikobakteri. Meski melimpah, pemanfaatannya masih belum meluas, seperti produksi air bersih atau bahkan air minum. Teknologi alternatif diperlukan untuk mereduksi kadar garam, partikel logam serta mikrobakteri yang terkandung dalam air laut untuk mendapatkan air bersih. Air bersih yang dimaksud adalah air yang bebas dari kotoran, bakteri yang merugikan, dan zat-zat lain yang bersifat merugikan bagi kesehatan manusia.

Air laut merupakan campuran dari $96,5 \%$ air murni dan 3,5\% zat lain, seperti garam, gas terlarut, zat organik dan partikel tidak larut. Kandungan garam setiap laut berbeda-beda. Air laut mengandung garam karena bumi penuh dengan garam mineral yang terdapat di bebatuan dan tanah (Prastuti, 2017).

Secara kimiawi, besarnya pengaruh air laut tercermin dari tingginya salinitas. Salinitas umumnya disebabkan oleh mineral yang terkandung dalam air laut yaitu ion klorida $55 \%$, sulfat $7,7 \%$, natrium $30,6 \%$, kalsium $1,2 \%$, kalium 1,1\%, magnesium 3,7\%, dan lain-lain 0,7\% (Wijayanto \& Sutanto, 2011). Air yang terlalu asin dapat membahayakan jika digunakan untuk kegiatan tertentu, dan berbahaya bagi kesehatan jika digunakan sebagai air minum, yang menyebabkan kegagalan pertanian, korosi pada peralatan dan bangunan yang terbuat dari elemen logam. (Darmawansa \& Jati, 2014).

Kandungan garam atau total padatan terlarut (TDS) yang tinggi memerlukan pengolahan lebih lanjut agar dapat digunakan sebagai air bersih atau bahkan nantinya sebagai air minum. Air dengan kandungan mineral tinggi (TDS tinggi) tidak layak diminum karena melebihi kebutuhan mineral tubuh. TDS air laut melebihi 3000ppm, yang tidak dapat langsung dikonsumsi oleh tubuh manusia. Menurut standar WHO, air minum dapat dikonsumsi jika kandungan TDS kurang dari 100 ppm (Nugraha \& Mahida, 2013).

Saat ini, penelitian telah berkembang untuk mengubah air laut menjadi air tawar, dari yang sederhana dan murah, seperti rumah kaca surya, hingga teknologi reverse osmosis yang mahal. (Abdelgaied, 2017; Iswadi, 2016; Krisdiarto et al., 2020; Rosari et al., 2014). Masyarakat perlu memperoleh pengetahuan dan model teknis yang tepat yang dapat membantu mereka menyediakan air bersih.

Adsorpsi merupakan salah satu bentuk dari sorption operation. Ada dua komponen penting dalam adsorpsi yakni fase bergerak (adsorbate) dan penjerap (adsorbent). Mekanisme proses adsorpsi pada dasarnya adalah proses penjerapan yang terjadi pada permukaan padatan. Proses transfer massa yang terjadi didasarkan pada permukaan yang aktif. Mulamula molekul mendifusi melalui pori-pori (macropore). Kemudian melalui mesopore. Kemudian molekul terjerap dalam pori-pori kecil (micropore) dan tertahan didalamnya (Bimantio, 2017).

Proses adsorpsi adalah salah satu cara untuk mengurangi salinitas air, yaitu dapat menggunakan adsorben sebagai media dalam penurunan salinitas diantaranya karbon aktif, tanah liat, abu terbang dan zeolit (Wibowo et al., 2017).

Hasil penelitian Badriyah dkk. (2020) menunjukkan bahwa perubahan konsentrasi $\mathrm{KOH}$ sebagai aktivator pada zeolit alam klinoptilolit tidak berpengaruh terhadap penurunan salinitas air di ketiga wilayah di Madura. Saat digunakan zeolit alam aktivasi $\mathrm{KOH} 5 \mathrm{M}$, salinitas optimal berkurang $20 \%$. Pada penelitian lain menggunakan zeolit, Agus (2018) menggunakan media zeolit sebagai adsorben untuk menyaring air laut dengan membandingkan variabel perbedaan ketinggian zeolit di kolom. Hasil percobaan menunjukkan bahwa tingginya nilai TDS, DHL, salinitas, klorin, dan natrium disebabkan oleh intrusi air laut. Filter zeolit yang digunakan sebagai media pengolahan dapat menurunkan TDS, dengan efisiensi rata-rata $55,01 \%-57,13 \%$, efisiensi rata-rata penurunan kadar DHL 51,64\%$54,57 \%$, dan efisiensi rata-rata penurunan salinitas 68,71\%-70,05\%. Diantaranya, rata-rata 
efek zeolit dalam menurunkan kadar natrium adalah 3,88\%-24,98\%.

Tujuan penelitian adalah untuk merancang desain alat pemurnian air laut menggunakan prinsip dasar metode adsorpsi. Alat yang dirancang diharapkan agar pengguna dapat menyesuaikan jumlah adosrben yang digunakan dengan memanfaatkan bentuk rancang bangun alat yang portabel dan dapat dibongkar pasang. Alat ini memberi manfaat dari segi portabilitas, daya jerap, kemudahan pengaplikasian dan pemeliharaan alat.

Hasil rancangan produk berupa alat pemurnian air laut menjadi bentuk luaran dalam bagian teknologi tepat guna. Rancangan alat dalam bentuk desain 2 dimensi dan 3 dimensi menjadi luaran lain dalam penelitian ini.

\section{METODE}

\subsection{Alat dan Bahan}

Alat utama dari penelitian ini adalah alat penjernih air laut tipe adsorpsi portabel, seperti terlihat pada Gambar 1. Alat pemurnian berbentuk kolom, dengan beberapa pelat sebagai bahan pengisi, yang meningkatkan waktu tinggal, sehingga proses pemurnian dapat dilakukan dengan sempurna. Alat terdiri dari 3 bagian, yaitu: top distributor, packing bed, dan bottom collector. Prinsip dari ketiga bagian tersebut adalah seperti puzzle yang dapat diatur jumlah packing bed-nya mengikuti kebutuhan pemurnian yang diinginkan. Ketiga bagian alat tersebut dihubungkan dengan sistem sekrup sehingga dapat dibongkar pasang sesuai kebutuhan.

Bahan isian kolom adsorber antara lain: Ceramic Biological Beads, Ammonite, Volcanic rock, Karbon aktif, dan Zeolit. Sedangkan bahan pembuat kolom dapat dibentuk dari PLA (Polylactic Acid), stainless steel, kaca, PVC, maupun akrilik, disesuaikan dengan kebutuhan dan biaya.

\subsection{Langkah Penelitian}

Konstruksi alat penelitian disusun sebagai bentuk representasi kolom adsorpsi yang portabel (Gambar 2), dimana selain kolom terdapat pula sistem sirkulasi air laut untuk menjamin proses filtrasi dapat berjalan dengan maksimal. Sistem sirkulasi menggunakan bak penampung sebagai buffer dan pompa sirkulasi sebagai pendorong dari bak ke input kolom.

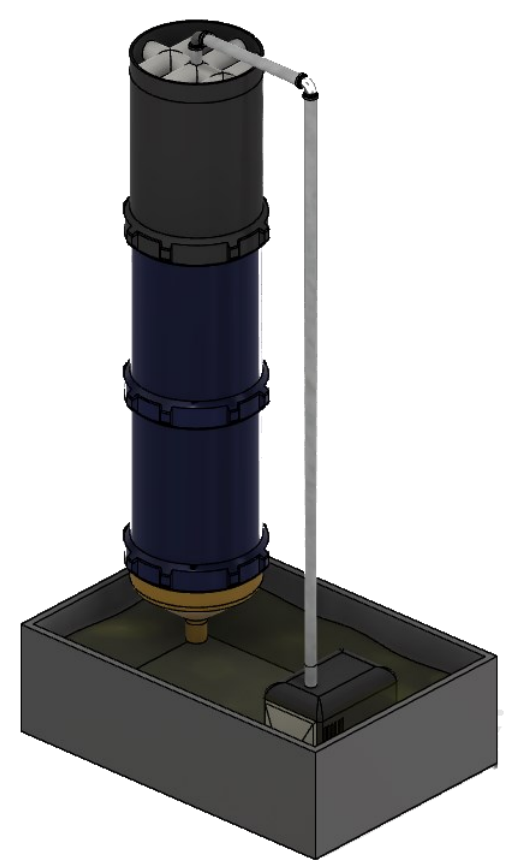

Gambar 1. Skema Kolom Adsorpsi Portabel Bersirkulasi

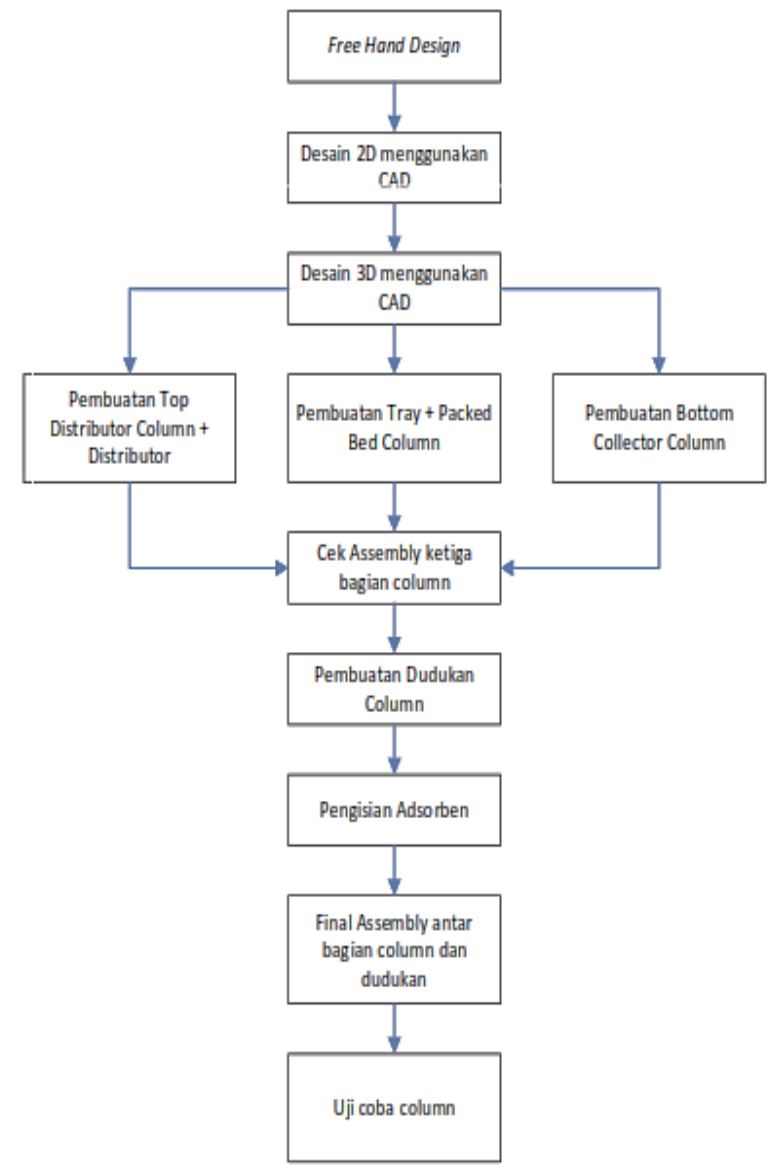

Gambar 2. Alur Kerja Desain Kolom Adsorpsi Portabel Bersirkulasi 
Gambar 3. Desain kolom adsorpsi terdiri dari tiga bagian.

Metode perancangan kolom Adsorpsi Portabel Bersirkulasi merupakan pengembangan dari alat yang dikembangakan oleh Bimantio (2020) dengan modifikasi pada bagian sistem sirkulasi. Proses desain dimulai dengan sketsa dasar 3 proyeksi. Kemudian, dengan bantuan perangkat lunak komputer, sketsa diubah menjadi model 3D sehingga dapat diproduksi dengan printer 3D menggunakan bahan PLA. Penggunaan bahan lain dapat dilakukan pula dengan tetap mengikuti basis template pada model 3 dimensi. Setelah komponen tercetak, dilanjutkan dengan proses menyusun alat menjadi satu rangkaian utuh sesuai dengan keperluan, seperti contoh pada Gambar 3. Proses perangkaian juga termasuk didalamnya proses pengisian bahan isian untuk adsorpsi. Setelah terisi, proses adsorpsi dapat dilakukan dengan mengalirkan sampel ke dalam kolom adsorpsi.

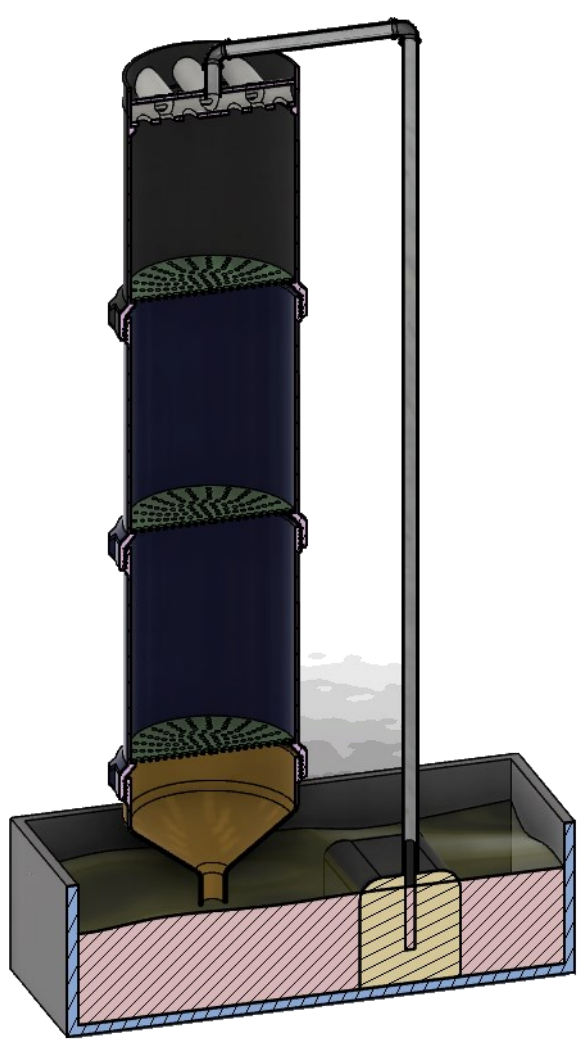

Gambar 3. Rangkaian Kolom Adsorpsi Portabel Bersirkulasi

\section{HASIL DAN PEMBAHASAN}

Konfigurasi dan bentuk kolom adsorpsi portabel bersirkulasi seperti terlihat pada

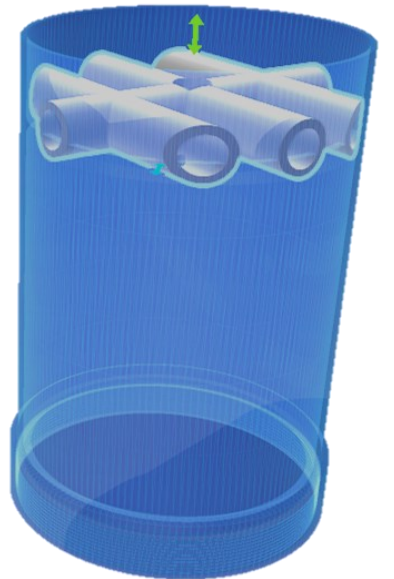

Gambar 4. Skema Bagian Top distributor

Top distributor (gambar 4), sebagai distributor aliran fluida kedalam kolom bagian atas. Berfungsi untuk memperluas bidang kontak antara cairan dengan adsorben. Diameter kolom yang dirancang adalah 6 inchi dengan ketebalan $2 \mathrm{~mm}$. Bagian top distributor dapat disambungkan dengan bagian packing bed atau bottom collector menggunakan sistem ulir. yang berada dibagian pipa distributor untuk menjamin sebaran cairan.

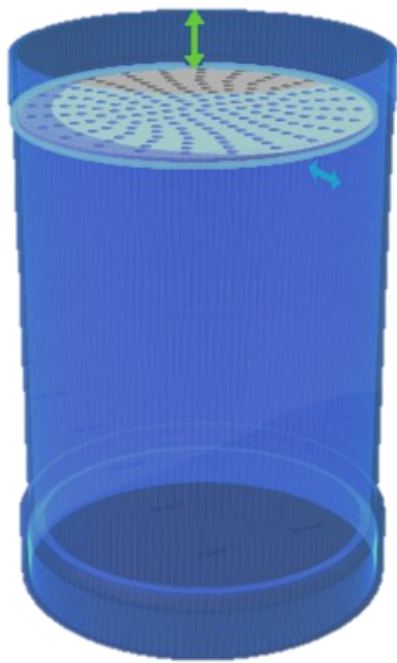

Gambar 5. Skema Bagian Packing bed

Packing bed (gambar 5), sebagai badan utama dasar adsorben pada kolom yang dialirkan. Adsorben ditumpu oleh plat dengan ketebalan $3 \mathrm{~mm}$, plat dilengkapi lubang distribusi aliran fluida, dengan ukuran lubang pada plat dengan diameter $5 \mathrm{~mm}$. Packing bed berdiameter 6 inchi dengan tebal $2 \mathrm{~mm}$, 
adsorben dapat ditaruh hingga ketinggian maksimal $17 \mathrm{~cm}$. Bagian bawah packing bed dapat disambungkan dengan bagian packing bed lainnya ataupun bottom collector, sedang bagian atasnya dapat dihubungkan dengan top distributor menggunakan sistem ulir. Jumlah packing bed dapat diatur sesuai dengan kebutuhan dan jumlah adsorpsi yang diperlukan. Jenis adsorben yang dapat ditempatkan pada plat beragam jenisnya bergantung pada jenis adsorben yang ditentukan. Alat ini dapat menjadi rangka dasar kolom adsopsi yang dapat mengakomodir berbagai jenis adsorben yang ada dipasaran maupun yang masih menjadi prototipe.

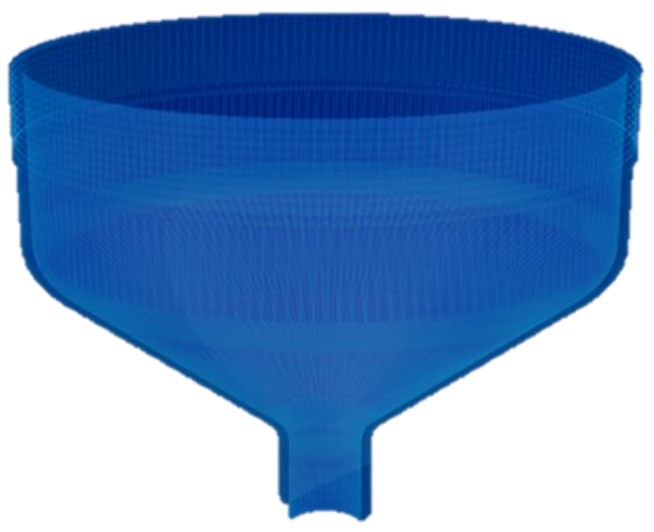

\section{Gambar 6. Skema Bagian Bottom collector}

Bottom collector (gambar 6), berfungsi mengalirkan fluida hasil adsorpsi ke penampung. Bagian ini berdiameter 6 inchi dengan tebal $2 \mathrm{~mm}$. Bentuk dibuat corong kerucut agar aliran dapat terpusat pada jalur keluaran berukuran $1 \mathrm{~cm}$. Bottom collector dapat dihubungkan dengan packing bed atau top distributor dengan menggunakan sistem ulir.

Kolom adsorpsi portabel bersirkulasi dapat dirancang menggunakan berbagai bahan konstruksi seperti PLA (Polylactic Acid), stainless steel, kaca, PVC, atau akrilik. Penyagga kolom terbuat dari besi. Contoh bentuk rangkaian hasil cetak 3 dimensi alat ini seperti terlihat pada gambar 7. Tinggi keseluruhan dari kolom dapat disesuaikan dengan kebutuhan adsorbsi yang diinginkan. Kolom ini bersifat portabel yang dapat dibongkar pasang yang bertujuan untuk kemudahan pemakaian, pembersihan, dan kustomisasi. Rancangan kolom ini masih dapat terus dikembangkan baik dari segi konstruksi, ergonomi, teknis, dan efektifitas. Kolom ini diharapkan mampu memenuhi kebutuhan pemurnian air laut berbasis adsorpsi yang dapat dikustomisasi, murah, dan mudah.

Penggunaan PLA dalam desain ini memberikan daya tahan dan kualitas bahan yang baik dibandingkan dengan PVC dan tidak seringkih bahan kaca dan tahan karat dibandingkan dengan besi. Konfigurasi bongkar pasang ini merupakan kelebihan utama dari desain alat ini dibandingkan dengan desain alat filtrasi air laut pada penelitian terdahulu. Pratama dkk. (2021) menggunakan bahan akrilik yang disusun secara teras yang membutuhkan penyangga dan biaya yang lebih besar dalam produksinya.

Sistem tray bertingkat pada alat ini menyempurnakan desain pemurnian bertingkat yang dirancang oleh Wijayanto dan Sutanto (2011), dimana dalam penelitiannya menggunakan bak terpisah yang disusun bertingkat dan dihubungkan dengan selang, sistem pemurniannya juga menggunakan metode elektrokoagulasi. Desain tersebut membutuhkan ruang yang luas, energi listrik, dan strukur pendukung untuk mendirikan alat. Kolom adsorpsi portabel yang penulis rancang menggunakan sistem ulir sebagai penghubung sehingga tidak membutuhkan alat tambahan dalam strukturnya serta bila dibutuhkan sistem elektrokoagulasi dapat pula ditambahkan sebagai add-on pada sistem ini.

Sistem sirkulasi yang dirancang menjamin agar proses filtrasi berlangsung secara kontinyu dan cepat sehingga hasil air bersih dapat diperoleh dengan segera. Hal ini menyempurnakan hasil penelitian Krisdiarto dkk. (2020) yang merancang Piramida Distilasi untuk pemurnian air laut, dimana dalam prosesnya memanfaatkan sistem evaporasi air laut memanfaatkan sinar matahari dalam kubah kaca untuk menjaga panas yang diterima. Sistem tersebut terbatas pada jumlah air yang dapat dimurnikan, semakin banyak jumlah air maka waktu penguapan akan semakin lama, metode tersebut juga bergantung pada cuaca dan intensitas cahaya matahari. Kolom adsorpsi portabel yang penulis rancang dapat mengolah hingga 10 liter air dalam setiap alirannya dan bisa terus bertambah bila ditambahkan kolomnya, karena sifatnya yang menggunakan ulir sehingga dapat selalu ditambahkan. 
Sehingga alat ini tidak terbatas pada kapasitas, cuaca, dan konfigurasi.

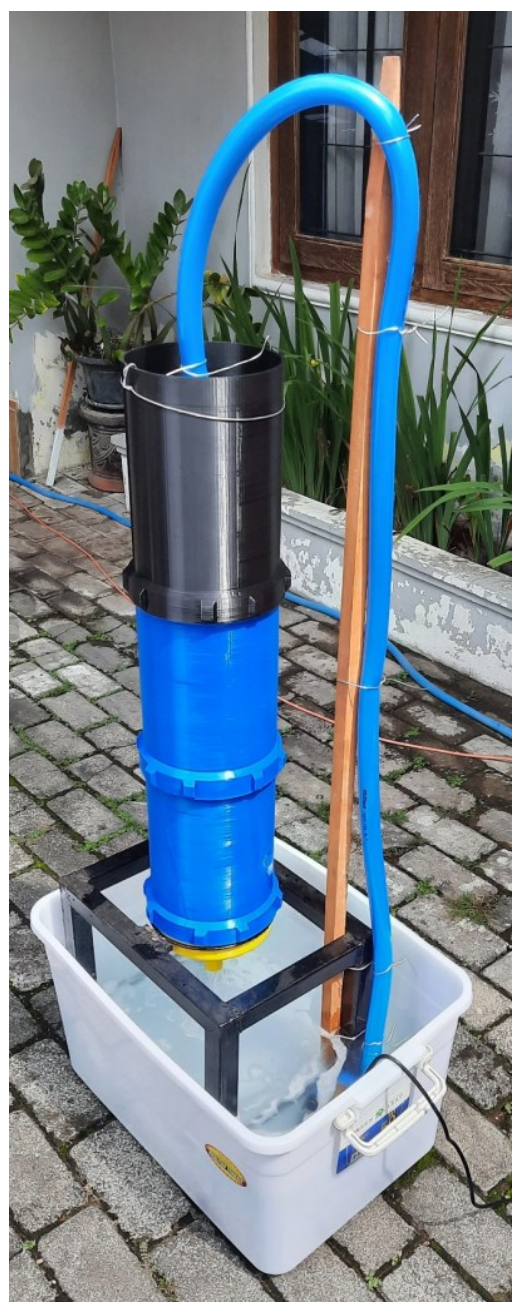

Gambar 7. Cetak 3 Dimensi Rangkaian Kolom Adsorpsi Portabel Bersirkulasi

\section{KESIMPULAN}

Dari penelitian ini telah dirancang sebuah rancangan unit kolom adsorpsi portabel bersirkulasi sebagai media pemurnian air laut yang sederhana. Kolom ini dapat dirancang menggunakan berbagai bahan konstruksi seperti PLA (Polylactic Acid), stainless steel, kaca, PVC, atau akrilik. Kolom ini memiliki rancangan dasar dengan diameter 6 inchi dan ketebalan $2 \mathrm{~mm}$. Adsoben ditumpu dengan plat berdiameter 6 inchi dan ketebalan $3 \mathrm{~mm}$. Kolom ini terdiri dari 3 bagian, yaitu: top distributor, packing bed, dan bottom collector, fitur utama ketiga bagian tersebut dapat dihubungkan menggunakan sistem ulir yang berguna ketika proses pembersihan, bentuk yang portabel, dan tingkat adsorpsi yang dapat diatur. Kelebihan ini diharapkan dapat mengatasi permasalahan atau kekurangan yang ada dari desain kolom adsopsi sebelumnya. Kolom ini diharapkan mampu memenuhi kebutuhan pemurnian air laut berbasis adsorpsi yang dapat dikustomisasi, murah, dan mudah.

Dalam perkembangan selanjutnya, rancangan kolom ini dapat diduplikasi sebagai media pemurnian berbasis adsorpsi lainnya seperti pemurnian biodiesel, bioethanol, air limbah, dsb.

\section{UCAPAN TERIMA KASIH}

Penulis mengucapkan terimakasih kepada Lembaga Penelitian dan Pengabdian Masyarakat Institut Pertanian STIPER Yogyakarta sebagai promotor dan sponsor dalam penelitian ini.

\section{DAFTAR PUSTAKA}

Abdelgaied, M. (2017). PERFORMANCE OF A PYRAMID SOLAR STILL WITH VCORRUGATED ABSORBERS PLATE: EXPERIMENTAL STUDY. Twentieth International Water Technology Conference-IWTC20.

Agus, I. Y. (2018). TEKNIK PENGOLAHAN AIRTANAH PAYAU MENJADI AIR MINUM DENGAN METODE ADSORPSI ZEOLIT DI DESA JANGKARAN, KECAMATAN TEMON, KABUPATEN KULONPROGO, DAERAH ISTIMEWA YOGYAKARTA.

UNIVERSITAS PEMBANGUNAN NASIONAL" VETERAN" YOGYAKARTA.

Badriyah, L., Restuaji, I., \& Luluk, L. (2020). Adsorpsi Salinitas Sumber Air Madura dengan Zeolit Alam Klinoptilolit Teraktivasi Basa. Jurnal Sintesis: Penelitian Sains, Terapan dan Analisisnya, 1(2).

Bimantio, M. P. (2017). Effect of Grain Size and Activation Time of Zeolite to Adsorption and Desorption of NH4OH and KCL As Model of Fertilizer-Zeolite Mix. Jurnal Konversi, 6(2), 20-27.

Bimantio, M. P., Oktavianty, H., \& Widyasaputra, R. (2020). Perancangan Desain Portable Fixed-Bed Composite Adsorber Column sebagai Media Pemurnian Biodiesel dengan Sistem 
Packing Bed. TEKNIK, 41(3), 253-260. https://doi.org/10.14710/teknik.v41n3.326 61

Darmawansa, W. N., \& Jati, D. R. (2014). Desalinasi Air Payau dengan Media Adsorben Zeolit di Daerah Pesisir Pantai Kecamatan Sungai Kunyit Kabupaten Mempawah. Jurnal Teknologi Lingkungan Lahan Basah, 2(1).

Iswadi, I. (2016). Rancang bangun alat pemurni air laut menjadi air minum menggunakan sistem piramida air (green house effect) bagi masyarakat pulau dan pesisir di kota Makassar. Jurnal Sains dan Pendidikan Fisika, 12(3), 300-310.

Krisdiarto, A. W., Ferhat, A., \& Bimantio, M. P. (2020). Penyediaan Air Bagi Masyarakat Pesisir Terdampak Kekeringan dengan Teknologi Desalinasi Air Laut Sederhana. DIKEMAS (Jurnal Pengabdian Kepada Masyarakat), 4(2), 25-31. https://doi.org/10.32486/jd.v4i2.532

Nugraha, D. H., \& Mahida, M. (2013). Kesiapan Masyarakat Menerapkan Teknologi Tepat Guna Pengolahan Air Minum (Studi Kasus: Pulau Palu'e, Nusa Tenggara Timur). Jurnal Sosial Ekonomi Pekerjaan Umum, 5(2).

Prastuti, O. P. (2017). Pengaruh Komposisi Air
Laut dan Pasir Laut Sebagai Sumber Energi Listrik. Jurnal Teknik Kimia dan Lingkungan, 1(1), 35-41.

Pratama, A., Rahmadianto, J. P. M. F., Pohan, G. A., \& Susanto, E. E. (2021). Analisa Perancangan Desalinasi Air Laut Dengan Variasi Filter Tempurung Kelapa Dan Variasi Temperatur Pemanasan. Jurnal Flywheel, 12(1), 1-5.

Rosari, T., Hadi, W., \& Masduqi, A. (2014). Desalinasi Air Payau Menggunakan Energi Solar Dengan Parabolic Trough. Jurnal Purifikasi, 14(1), 55-64.

Wibowo, E., Rokhmat, M., Sutisna, Khairurrijal, \& Abdullah, M. (2017). Reduction of seawater salinity by natural zeolite (Clinoptilolite): Adsorption isotherms, thermodynamics and kinetics. Desalination, 409, 146-156. https://doi.org/https://doi.org/10.1016/j.de sal.2017.01.026

Wijayanto, D., \& Sutanto. (2011). MODEL ALAT PENAWAR AIR TANAH TERINTRUSI AIR LAUT ( AIR PAYAU ) DENGAN PROSES ELEKTROKOAGULASI. PoliTeknologi, 10(2), 171-180. 